\title{
The Significance of the Mobile Social Platform in the Ideological and Political Education of College Students
}

\author{
Ma Jun \\ Journal Editorial Department, Weinan Normal University, Weinan, Shaanxi, 714099
}

Keywords: Mobile Social Platform, College Students' Ideological and Political Education, SWOT Analysis

\begin{abstract}
Mobile social networking platform serves as the main channel between the media for information exchange and maintenance of the relationship, firmly controls life learning situations of users, has an important significance for the formation of personality, hobbies and habits of users interested in political thought, especially college students in the adolescent stage, the ideological and political education and the quality of the success or failure of affected mobile social networking platform to a great extent. Therefore, SWOT analysis is important and necessary for mobile social networking platform and in the ideological and political education, at the same time, the paper put forward countermeasures of ideological and political education in mobile social platform scenarios, in order to provide certain theoretical guidance for ideological and political education of college students in the new era.
\end{abstract}

\section{Introduction}

In August 2015, Pugh released the "youth and friendship", science and technology research report shows that young people aged 15-22 in 57\% from the Internet to know new friends, and there are $29 \%$ people with more than 5 users, social networking platform for young people to make new friends, and is of great significance to interact with friends, maintain friendship [1]. WeChat, micro-blog, QQ, Facebook, Twitter and a number of social networking platforms on mobile devices like gorgeous bright gathered more young people, especially college students active users, through data analysis, accurately grasp the user's interest preference and consumption habits, and monopoly of the user groups most of the consumer scene that has an important influence on College Students' Ideological and political education [2].

\section{The Current Situation of the Use of Mobile Social Platform for College Students}

\subsection{A large amount of time for student groups to use mobile social platforms}

According to a survey of penguin, people occupy 25.8\%, 16.7\%, 6.8\%, 44.9\%, 27.5\% of mobile media in the bed, waiting for or taking the means of transportation, eating, resting and leisure. It can be seen that mobile reading consumption has been extended to every life scene of the user, and it is almost "adjoint" media consumption. In the mobile reading consumption army, the youth group dominated by college students occupied half of the world. "The 2016 third quarter social networking report" released by Global WebIndex, the world's largest digital consumer market research institution, shows that the average daily access of mobile Internet social networking platforms to young adults is 1.77 hours, and generally has multiple social accounts [3]. Tencent's first quarter 2017 financial report showed that the current monthly active users of WeChat and QQ reached 938 million and 861 million, respectively. Facebook, a global social platform, has reached 1 billion 400 million of its users, and more than half of them are young users.

\subsection{The diversity of the use of mobile social platforms for College Students}

Because of their special age and living environment, college students have strong communication needs. Through mobile social networking platform, college students can not only 
share information with each other, but also get support from friends or peers. Diversity of contacts need to use group diversity in mobile social platform in the form of college students, the students use the mobile social networking platform mainly in the following categories: one is the WeChat, QQ, Facebook based universal dating platform, such a platform for information transmission and maintenance of interpersonal relationship between the main. The two is the game social networking platform [4]. This social platform develops along with the development of mobile media. Especially in recent years, with the big screen smart phone as the carrier of hand travel, such as DOTA, the king glory and so on, it is mainly in the team game to narrow the distance between friends. Three is a live video social platform, live video social platform is a new social platform developed in the last two years, the fish, six rooms and other video broadcast platform of massive young loyal users polymerization. Four is the famous micro-blog, to college students as the outstanding position of fans groups tend to occupy the micro-blog micro-blog celebrity list, such as TFBOYS, Han deer and Guan Xiaotong. These all kinds of social platform plays an important role in the daily life of the students, they become the college students to communicate with others, to obtain external information, such as the main platform for personal expression of ideas, impact, is very important for college students' Ideological and political education. Therefore, in the mobile social platform bursting under the background of the development, from the start the ideological and political education, SWOT analysis has very important practical significance to the practical effect of the mobile social platform in Ideological and political education of College students.

\section{The SWOT Analysis of the Mobile Social Platform in the Ideological and Political Education of College Students}

\subsection{Strengths analysis}

College Students' Ideological and political education mainly includes the education of College Students' political beliefs, social ideals and their outlook on life. The mobile social networking platform as an effective channel for the communication between college students and the outside world has inherent advantages in the ideological and political education of college students. First, the mobile social platform provides a rich content for the ideological and political education of college students. The use of WeChat QQ, the official school, micro-blog and other mobile social networking platform to effectively aggregate family, teachers and students of education subject, set up a class for high viscous community units, and the use of various forms of mobile social networking platform to voice, pictures, video and other information dissemination way, the ideological and political education for all-round, three-dimensional students compared with the didactic or text reading style education tradition, has the characteristics of large information capacity, wide spread range, good communication effect. Second, the mobile social platform provides a new channel for college students' Ideological and political education. Parents and teachers can change the use of WeChat circle of friends, QQ space, micro-blog and other personal observation of students' psychological, ideological and political aspects of knowledge, from the one to one communication, group chat, friends, use WeChat and other aspects of a comprehensive understanding, analysis of the existing ideological and political issues, implementation early detection and correction of the problem [5]. Third, from the function of communication, mobile social networking platform provides a communication platform for the diversification of college students, with the help of common communication, one can communicate with the teacher, consult the relevant learning problems; at the same time in the group chat, group chat with classmates, enhance the friendship between classmates; in daily life. Can communicate with their parents, relatives and family, to enhance their ability of communication and coordination, is beneficial to the healthy development of college students. Fourth, from the function of information acquisition, college students can read some meaningful, academic, popular and literary articles through the public service number of mobile social platform, improve their reading volume and enhance their discrimination and cognitive ability. At the same time, it can obtain some public information from the circle of friends to enhance the ability to understand society, to know the society and to look at 
the society correctly. Fifth, from the entertainment function, mobile social networking platform has powerful game function, can let the student in the study, a simple game entertainment, to work and rest, while some puzzle games can also train students' image perception ability and logical thinking ability.

\subsection{Weaknesses analysis}

Mobile social networking platform is a double-edged sword for users, it will produce many negative effects on college students in the psychological and physiological user specific features: first, mobile social networking platform to distract the attention of students. College students are the main body of Ideological and political education, ideological education should be good, become the society the most pure group. However, with the continuous development of the media, and some bad information, decadent culture on college students are constantly eroded, bad atmosphere let them to "accept" in society, their personality and psychological influence. In the media age of college students, in the face of the rich information content is complex, they are more passive than active choice, and the dissemination of the contents of mobile social networking platform fragmented forms of communication and superficial is very easy to destroy the students' attention, and make students learn in turn depend on media production, fragmentation of students study life time [6]. Second, the unique characteristics of virtual mobile social networking platform, students may lead to individualism egoism. Mobile social media because of its portability, easy to use, which makes some students addicted to the virtual social network in inextricably bogged down in in real life, out of class, refused to participate in collective activities, alienated students, seriously affecting the college students' interpersonal communication, if some information is forwarded in the process of being misunderstood, it may further increase the barriers and contradictions between the students. At the same time because of the lack of effective social media supervision, money worship, hedonism, egoism and other bad ideas through the media widely, eroding the mind. Third, increase the difficulty of the ideological and political education of College students. Mobile social networking platform as a new thing, because of its shorter development time and rapid spread, the relevant laws and regulations are not perfect, the government and other relevant departments of the management there are many gaps, schools, families and educators are lack of education guidance management experience, so that students can easily access to information includes not only uneven in quality [7]. A large number of false, contrary to ethics, violation of law information, there are also a large number of hidden or with feudalism and pornography, violence information. This kind of bad information through mobile social networking platform among students to spread rapidly in the viral way, a serious impact on the high school ideological and political education, confusion of the value orientation of college students and moral cognition.

\subsection{Opportunities Analysis}

First, since the media has integrated the advantages of many information resources and media forms, it has provided a new space for the ideological and political education in middle school and built a broad platform. Ideological and political educators can make use of this new form of platform to expand access to educational resources and enrich the means of education. It provides a broad theory and practice platform for middle school ideological and political education, without time and space restrictions, to spread positive energy, to promote value orientation and so on. At the same time, since the media with huge capacity, strong interactivity, multi form, wide radiation. This provides a wealth of rich network resources for ideological and political workers. Break through the original narrow educational space and communication path, open the educational space. Through the network, the way of communication between the three schools, students and parents is opened up naturally [8].

Ideological and political education in middle school is a required course for college students to carry out ideological and political education systematically, Marx's common sense education and socialist education with Chinese characteristics. It is of great importance for college students to establish correct world outlook, outlook on life and values. And ideological and political education is also the objective foundation and spiritual pillar of the all-round development of College 
Students' morality, intelligence, body and beauty. It can be seen that ideological and political education occupies a very important part in systematic education, and the application of media can provide a more efficient and convenient way for the implementation of Ideological and political education. In particular, the advantages of we-media can be transformed into temporal. The time advantage is mainly reflected in the speed advantage of disseminating information resources. Through we-media, the fresh educational information resources can be spread widely for the first time, so that students can receive ideological and political education in time. The spatial advantage is mainly embodied in the accessibility of the content of communication. As far as traditional media channels are concerned, new educational information can strengthen the connection and communication across different regions. For remote mountainous areas, if conditions permit, the convenient path of mobile Internet access is far more than the paper media. The forum of related websites not only improves the rich resources of rural college students' spare time learning, but also provides a platform for communication for their own voice. Since the diversification of media transmission channels, middle school campus can also feel rich and colorful ideological and political education, stimulate their curiosity, and to some extent, it can encourage children to take the initiative to accept information, learn information and improve their learning enthusiasm.

\subsection{Threats analysis}

Mobile social networking platform provides a new channel for the ideological and political education, also showed the two sides of the problem, from the adverse information dissemination, dissemination of false information, making ecological negative growth and WeChat fraud, had a negative impact on College Students' Ideological and political education. These negative effects have a great impact on the ideological instability, immature mentality of college students, to make the short-term thinking, the idea of life long shaken, can make its "three views" deviation, is not conducive to the growth and development of College students. First, the mobile social platform challenges the leading position of University Teachers' Ideological and political education. In traditional ideological and political education, teachers are guided by college teachers, and textbooks are used as media. Teachers have a purposeful, planned and organized education, and face to face teaching exchanges between teachers and students [9]. Mobile social networking platform for information and various media point of view in the first time almost a superb collection of beautiful things, and presented to the students so that they will. Outside the political class, college students have gained more implicit education than the classroom. This makes the traditional ideological and political education lack of attraction, infection and penetration for modern college students. A book, a mouth, and a chalk have been unable to meet the needs of college students. Second, the mobile social platform reduces the foresight of the University Ideological and political educators on the monitoring of public opinion. In the former ideological and political education, the educators foresee the problem ahead of time and make clear contents and methods of Ideological and political education. In the mobile social networking world, the object of Ideological and political education can focus on the mobile social platform that they are interested in, and educators can only focus on the specific part, so it is difficult to control the information received by college students. There are various unhealthy information in the process of information dissemination in mobile social platform. Sometimes there are rumors in politics, which are not foreseen by ideological and political educators. Third, the mobile social platform poses a challenge to the traditional carriers and methods of Ideological and political education. The carrier of traditional college students' Ideological and political education is mainly carried out in a certain time and space, such as theme specific theoretical teaching, conference learning, publicity report and other educational activities. The ideological and political educators can control their main factors for the purpose and consciousness of education, so that the traditional carrier is easier to grasp. The emergence of mobile social platform makes college students receive information in a way that breaks the limit of time and space. Juvenile judgment and discrimination are limited, and it is likely to be affected and corroded by bad information in the information rich carrier. 


\section{Conclusion}

Mobile social platform has become an irreplaceable new media in the current network era. At the same time, the traditional way of Ideological and political education has been unable to meet the inherent needs of contemporary college students. How to make good use of the double-edged sword of mobile social platform and how to take positive and effective measures and Countermeasures to prevent problems in Ideological and political education work is a problem we need to explore continuously.

\section{References}

[1] Zhao H. Significance of Chinese Traditional Culture Education in College Ideological and Political Work [J]. Journal of Huaihai Institute of Technology, 2017, 24(1):41-46.

[2] Li Q, Wu M, Han L. Multidimensional ideological and political education of college students based on the computer platform[J]. Agro Food Industry Hi Tech, 2017, 28(1):871-875.

[3] Zhong Z. To Strengthen Campus Cultural Construction in Institutions of Science and Engineering to Promote Ideological and Political Education of College Students [J]. International Journal of Academic Research, 2015, 5(5):386-392.

[4] Huang Z, Gao S. The Enlightenment on Mozi Educational Thoughts for Contemporary College Students' Ideological and Political Quality Education [J]. Journal of Guangdong Industry Technical College, 2012, 23(1): e5-e9.

[5] You-Shi W U, Zhao B X, Zhao L X. On the Significance of Increasing the Effectiveness of Ideal and Faith Education in the College Ideological and Political Theory Course [J]. Journal of Zhangjiakou Vocational \& Technical College, 2011, 72(3):699-702.

[6] Zhao H. Significance of Chinese Traditional Culture Education in College Ideological and Political Work [J]. Journal of Huaihai Institute of Technology, 2017, 24(1):41-46.

[7] Li Q, Wu M, Han L. Multidimensional ideological and political education of college students based on the computer platform[J]. Agro Food Industry Hi Tech, 2017, 28(1):871-875.

[8] Wang K. Research on multi-dimensional ideological and political education of college students based on computer platform [J]. Revista De La Facultad De Ingenieria, 2017, 32(8):447-454.

[9] Yinxiang Z. Efficiency of public opinion in social network in the ideological and political education of college students [J]. Agro Food Industry Hi Tech, 2017, 28(1):693-696. 